\title{
Trichogramma chilonis as Parasitoid: An Eco-friendly Approach Against Tomato Fruit Borer, Helicoverpa armigera
}

\author{
S. S. Abbas ${ }^{1}$, M. F. Shahzad ${ }^{1}$, Jamshaid Iqbal ${ }^{1}$, Ayat Ullah ${ }^{1}$, Asma Batool ${ }^{1}$, Muhammad Nadeem ${ }^{1}$, H. A. Begum ${ }^{1}$, \\ Hafeez-ur-Rehman ${ }^{1} \&$ Khalid Muhammad ${ }^{2}$ \\ ${ }^{1}$ Department of Entomology, Faculty of Agriculture, Gomal University, Pakistan \\ ${ }^{2}$ Institute of Microbiology, Faculty of Veterinary and Animal Sciences, Gomal University, Pakistan \\ Correspondence: M. F. Shahzad, Department of Entomology, Faculty of Agriculture, Gomal University, Pakistan. \\ Tel: 92-345-714-0174. E-mail: dr.faisal@gu.edu.pk
}

Received: November 20, 2019

Accepted: December 20, 2019

Online Published: January 15, 2020

doi:10.5539/jas.v12n2p167

URL: https://doi.org/10.5539/jas.v12n2p167

\begin{abstract}
Helicoverpa armigera (Hübner) is a major pest of several crops, e.g., Tomato, cotton, pigeon pea, and chickpea suffered by this insect in various parts of the worldwide. Trichocards as parasitoids regarding the different release levels of Trichogramma chilonis were used to evaluate the effectiveness against tomato fruit borer, Helicoverpa armigera as well as five insecticides with new chemistries were used to find out the comparative bio efficacy, which were relatively safer to human and environment, i.e., Capital plus (Beta-Cyfluthrin + Triazophos, 41.7\% EC) $500 \mathrm{ml} /$ Acre, Commando (Acephate, 97\% DF) $62 \mathrm{~g}$, Border (Profenofos + Lambda Cyhalothrin, 61.5\% EC) $500 \mathrm{ml} /$ Acre, Polytrin C (Cypermethrin + Profenofos, 440 EC) $500 \mathrm{ml} /$ Acre, Profit (Emamectin Benzoate, 1.9\% EC \& 90\% Tech.) $500 \mathrm{ml} /$ Acre. We also compared the insecticides with trichocards. There were 3 treatments, T1 Profit (Emamectin Benzoate, 1.9\% EC \& 90\% Tech.) $500 \mathrm{ml} / \mathrm{Acre}, \mathrm{T} 2$ (16000) of biological control agent (egg Parasitoid) and T3 (control plot). 16000 eggs of the parasitoid Trichogram chilonis, released per hectare were most effective in controlling tomato fruit borer. Out of the five insecticides tested, Border proved to be the best one, followed by Profit and Capital Plus in reducing the percent infestation of tomato by tomato fruit borer. In the third experiment, Profit gave best result followed by the Trichograma. chilonis cards with 16000 eggs per hectare. Among the tested insecticides, treatments sprayed with Border gave maximum yield $(6179.0 \mathrm{~kg} / \mathrm{ha})$, followed by Profit \& Polytrin C. Cost benefit ratio shows that highest net return (46.45 BCR) was obtained with Trichograma chilonis cards released plots followed by Profit. Trichocards are suggested for the controlling of Helicoverpa armigera as best substitute for insecticides. The use of trichocards practice have very effective role to protect the soil moreover, this practice may have significant role to protect the soil and save the natural resources from insecticides pollution.
\end{abstract}

Keywords: biocontrol, insecticides, insecticides pollution, trichocards

\section{Introduction}

Tomato (Lycopersicone esculentum Mill.) a rich source of vitamin A, C and minerals (Saleem et al., 2013). The fruits (tomatoes) are eaten as raw or cooked as well as large quantities of tomatoes are used to prepare paste, soups, ketchup, pickle, juices etc (Heuvelink, 2018). Tomato constitutes an important part of human diet, hence it grown in tropical and subtropical regions of the world. It is important from economic point of view because it gives high yield. Tomato can easily attacked by insect pests, i.e., jassids, aphids and fruit borer and diseases as compared to other crops (Katroju et al., 2014). In Pakistan there are several factors responsible for low tomato production, i.e., poor quality seeds, disease and insect infestation etc. (Lange \& Bronson, 1981). Due to the attack of many insect pest, considerable reduction in tomato yield has been reported (Hoffmann et al., 2001). Tomato fruit borer Helicoverpa armigera is major threat among the insect pests of tomato causing economical loss (Talekar et al., 2006). Annual crop losses about 5 billion US dollar caused by Helicoverpa armigera alone (Sharma et al., 2016). In Pakistan, 32.37\% fruit damage caused by Helicoverpa armigera where fruit loss (54\%) was noticed in Peshawar, K.P.K (Usman et al., 2013).

Tomato fruit borer cause serious damage to tomato fruit in larval stage. During April-May the adult moths generally appears on leaves and lay eggs (Reddy \& Kumar, 2004). The full grown larva completes its development inside the fruit and bore inside tomato fruit. All larval stages (5-6 instars) infested tomato (Sharma 
et al., 2011). In its developmental period the young one comes from one fruit to another. Full grown larvae will then come from tomato fruit, drops down and pupation period starts in soil. Up to 12 fruits can damage by single larvae therefore, farmer got great loss and lowers the market value of the fruit (Hussain et al., 2015). Tomato fruit borer is a polyphagous pest in tomato crop causing huge economic loss to different crops (Shah et al., 2013). In tomato crop $81 \%$ of the total insecticides are used to overcome this insect pest in Pakistan which shows the severity of the pest incidence. Due to their easy availability and applicability, chemical insecticides are generally preferred for the control of pest but their excessive and indiscriminate use has resulted in plethora of problems, e.g., resurgence of minor insect pests, insecticidal resistance in insects, death of natural enemies and non-target species and their residual effect in harvested produce leading to various health hazards, besides the increased cost of cultivation per unit area (Pimentel, 1995). Beside chemical insecticides host plant resistance also plays a key role to reduce losses to crops (Senthil-Kumar \& Mysore, 2012). Different bacterium Bacillus thuringiensis $(\mathrm{Bt})$ varieties are available nowadays, but there are restrictions to adopt $\mathrm{Bt}$ crops, like tomato which is used daily in human beings foods all over the world. There are also some barriers in adoption of Bacillus thuringenesis tomato varieties (Romeis et al., 2008). Moreover, majority of farming community in Pakistan are poor as well as they have lack of latest skills and storage facilities that's why farmers cannot afford expensive Bt varieties because marketing of such consumable commodities are unreliable and miserable. Less chances of growing resistant tomato varieties under the above mentioned circumstances, and in future crop has to be sown with substitute crop safety practices. These replacement practices although have less number of success stories, farmers have no choice other than pesticides to control the pest to save their crops (Nadeem \& Hamed, 2011). Therefore, the selection of the most appropriate parasitoid species is necessary in integrated control program. The most commonly used natural enemy in the world are Trichogramma species $(\mathrm{Li}, 1994)$ because they attack many important crop insect pests and their mass rearing is easy. In the world, round about nine species of Trichogramma are raised in private and also in government sector and released annually on 81 million acres of agricultural crops and forests trees in 31 countries ( $\mathrm{Li}, 1994)$. Recognizing the Trichogramma potential as a biological control agent, mass rearing of Trichogramma is used for insect control in the early 1900 by the Entomologists. Parasitism level fluctuates significantly in diverse habitats, i.e., plant parts or plant as a whole on which the host eggs are present. Moreover, Plant chemistry, structure, volatiles and colour are also considered as necessary for fluctuation of parasitism level (Romeis et al., 2005). Different species of Trichogramma (Trichograma evanescens, Trichograma poliae and Trichograma chilonis) are being reared in private or government laboratories and used as natural enemy of agricultural insect pests in the world (Hoffmann et al., 2001; Li, 1994). Muhammad et al. (2008) reported that Trichograma chilonis have high effectiveness if combined with other control strategies. Although biological control agents play an important role in agriculture but chemical control is still very important. Hence, attempts were made to evaluate the efficacy of different newer and bio-rational insecticides for the supportable, management of tomato fruit borer on tomato (Singh et al., 2012). Integrated use of chemical and biological control methods are most important strategies for persistence of Integrated Pest Management (IPM). Therefore, IPM programs should be estimated carefully for induction because of the side-effects of pesticides on biocontrol agents (Stark et al., 2007). This study was accomplished to determine the efficiency of Trichogrammma chilonis in field conditions against tomato fruit borer, Helicoverpa armigera as well as the effect of different newer and bio-rational insecticides against tomato fruit borer, Helicoverpa armigera. Moreover, the comparative efficacy of bio control agent and insecticides for the control of tomato fruit borer, Helicoverpa armigera was also analyzed.

\section{Materials and Methods}

Comparative bioefficacy of selected insecticides and effectiveness of Trichogramma chilonis as parasitoids of tomato fruit borer, Helicoverpa armigera were carried out at Agricultural Research Institute Dera Ismail Khan $\left(31.86^{\circ} \mathrm{N}, 70.90^{\circ} \mathrm{E}\right)$. Experiments were conducted to study the efficiency of Trichogrammma chilonis against tomato fruit borer and to determine the effect of different insecticides against tomato fruit borer, Helicoverpa armigera. The material used in experiments were the 1) spray pump, 2) host rearing cages, 3) rearing cages, 4) wheat, 5) paper cards, 6) glue, 7) camel-hair brush, 8) water, etc.

Experiments were conducted in RCBD designs which were replicated three times. Plot sizes were kept $144 \mathrm{~m}^{2}$. All the experiments were uncovered for insect pest infestation. Normal agronomic practices were carried out for both of the experiments.

\subsection{Effectiveness of Trichogramma chilonis as Parasitoid of Tomato Fruit Borer, Helicoverpa armigera}

The experiment was consisting of three treatments and a control. Different intensities, i.e., $(16000,14000$, and 12000) of biological control agent (egg Parasitoid), i.e., spp. Trichogramma chilonis were used as treatments. Rate of individuals per release was kept $(1600,1400$, and 12000) per acre and a total of eight releases were made 
after eight days interval starting from the infestation of the target insect pest. Tricho Cards were installed after the infestation at evening time (to provide protection from U.V. rays). Data was recorded at each harvest of tomato fruits.

Table 1. Detail of treatments used in experiment

\begin{tabular}{lll}
\hline S\# No. & Treatment & Treatment detail \\
\hline 1 & T1 & 16000 eggs Trichogram. chilonis \\
2 & T2 & 14000 eggs Trichograma chilonis \\
3 & T3 & 12000 eggs Trichograma chilonis \\
4 & T4 & Un treated \\
\hline
\end{tabular}

Data was taken on total No. of fruits and infested fruit to count out the percent infestation was work out by the following formula, i.e.,

$$
\text { Mean Fruit Damage (\%) }=\frac{\text { Damaged Number of Fruits }}{\text { Total Number of Fruits }} \times 100
$$

\subsection{Rearing of Host}

Species, i.e., chilonis reared under laboratory conditions on Sitotroga cerealella eggs, were used for the experiment. Glued cardboard each with squares approximately 250 Sitotroga cerealella eggs, was put to recently emerged females for 24 hours. The cards with a parasitism were transferred to another glass tubes and properly until pupation (192 hours).

\subsection{Comparative Bio-efficacy of Selective Insecticides}

This experiment consists of five treatments including a control. Five Different kinds of chemistries were used as treatments.

Table 2. List of insecticides used in the experiment

\begin{tabular}{llll}
\hline Treatments & Brand names & Active ingredient & Dose/Acre \\
\hline T1 & Capital plus & Beta-Cyfluthrin + Triazophos, 41.7\% EC & $500 \mathrm{ml}$ \\
T2 & Commando & Acephate, 97\% DF & $62 \mathrm{~g}$ \\
T3 & Border & Profenofos + Lambda - Cyhalothrin, 61.5\% EC & $500 \mathrm{ml}$ \\
T4 & Polytrin C & Cypermethrin + Profenofos, 440 EC & $500 \mathrm{ml}$ \\
T5 & Profit & Emamectin Benzoate, 1.9\% EC \& 90\% Tech & $200 \mathrm{ml}$ \\
T6 & Control & Water & - \\
\hline
\end{tabular}

\subsection{Experimental Procedure}

Total number of damaged fruits and healthy fruits from each plot at each picking was calculated and then converted to percent basis. Similarly, marketable fruit yield were recorded and converted to quintals per acre to find out incremented cost benefit ratio (IBC) and additional net profit. For each plot total number of infested tomato fruit and its weight were counted separately. By adding the yields of tomato per picking at each plot the total yield of tomato was determined.

$$
\begin{gathered}
\text { Yield }=\text { Total wt. of tomato picked from each plot } \\
\% \text { Weight loss }=\frac{\text { Total weight of damage fruit }}{\text { Total weight of tomato }} \times 100
\end{gathered}
$$

Knapsack sprayer (Jacto power Sprayer) with hallow cone nozzle was used in this experiment. One time and only one row was sprayed to ensure the accuracy of chemicals applications. Surgical gloves, masks and long rubber boots were worn by the applicator as safety measures. Good timing is very much essential for a successful plant pest control. Plant behavior, air movement, insects activity was given special attention.

\subsection{Comparative Percent of Fruit Infestation in Insecticides Application and Trichogramma chilonis Releases}

To compare the insecticide with Trichocards, the field was divided into three plots. A buffer zone of $5 \mathrm{~m}$ was maintained. There were three treatments, i.e., T1 (Border $500 \mathrm{ml}$ ), T2 (16000) of biological control agent (egg 
Parasitoid) and T3 (control plot). The synthetic insecticide Border was applied during reproductive stage of the crop when Helicoverpa armigera appears to be severe economic damage. The quantity of spray fluid was at 500 liters per hectare. In the fields the parasitoid of Trichograma chilonis from which adult appearance were expected within about 24 hours were fixed in the field. For control plot only water was sprayed. Fruit damage data was recorded at the time of harvesting through counting number of damaged fruit and total number of fruits.

\subsection{Cost benefit ratio}

The cost benefit ratio was determined for each treatment by using the following formula, i.e.,

$$
\text { Benefit Cost Ratio }=\frac{\text { Total income }}{\text { Total cost }}
$$

\subsection{Statistical Analysis}

Analysis of variance (ANOVA) was carried out to determine effectiveness of Trichograma chilonis against Helicoverpa armigera, by using statistical program Statistix 8.1. Similarly, least significant differences (LSD) was calculated with Duncan's Multiple Range test for adult emergence of Trichograma chilonis against insecticidal exposures by using Statistix 8.1 at a significance level of $\mathrm{P}<0.05$ (Steel et al., 1997).

\section{Results and Discussion}

\subsection{Effectiveness of Trichograma chilonis Against Tomato Fruit Borer Helicoverpa armigera}

Efficiency of Trichogramma chilonis are summarized in Figure 1. The results show a decrease in the population of H.armigera larvae over the period after installation of Trichocards. Trichograma chilonis was effective and reduced the Helicoverpa sp. infestation when released under field conditions which successfully showed its role and suitability with prevailing environmental conditions in control of Helicoverpa sp. The borer infestation is shown on Y-axis while weekly data is shown on x-axis. Result indicated that Trichograma chilonis and their number of releases play a key role in the control of pest infestation. This graph clearly showed that population of Trichograma chilonis is directly proportional to the percent infestation caused by Helivoverpa armigera. The population of Trichograma chilonis was low and infestation of Helicoverpa armigera remained high during early weeks but with increasing concentration of Trichograma chilonis parasitized eggs population gradually, decreased in the population of Helicoverpa armigera was recorded. The population of Helicoverpa armigera decreased as the duration of biocontrol agent increased which shows the potential of parsitoid in controlling the pest. Data presented in Figure 1 showed that lowest infestation was noted in (T1) throughout the study period, followed by (T2) \& (T3). However In control (T4), infestation was higher than rest of all the treatments. All the treatments were found significantly different with each other during the entire study. Variation was found among the Trichocard released fields compared with the control. The present findings were in similarity with the findings of Saljoqi and Walayati (2013). However the result of Ahmad et al. (2012) was contradiction to the present findings.

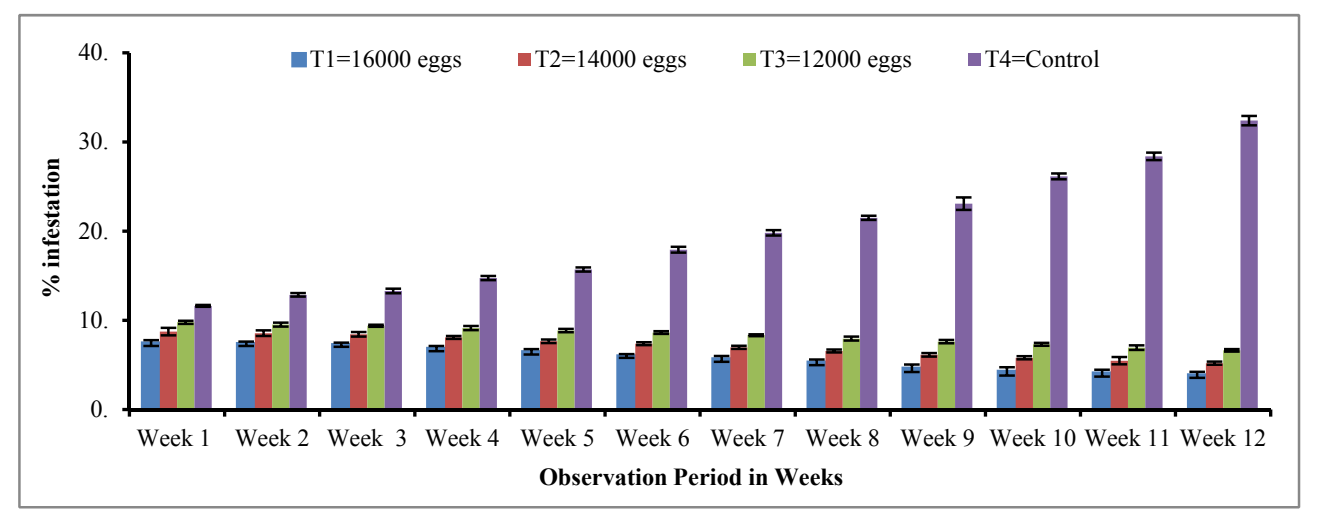

Figure 1. Mean percent infestation of Helicoverpa armigera larvae in tomato fields' after different releases of Trichograma chilonis at ARI, DI Khan 


\subsection{Percent Infestation of Tomato Fruit Borer Treated With Different Releases of Trichocards}

Table 3 shows the effect of Trichogrma chilonis releases against Helicoverpa armigera. Maximum infestation was noticed in untreated plot, and is statistically different from rest of all other treatments. The percent population of tomato fruit borer revealed that all the treatments have more impact over control. Highest infestation was noticed in control (19.77\%) treatment, followed by T3 (9.39\%), T2 (7.54\%) and T1 (5.86\%). Treatments $\mathrm{T} 1$ and $\mathrm{T} 2$ were statistically at par with each other.

Tomato fruit borer in comparison to single and double release had more impact on reducing the Helicoverpa armigera. The reasons are that Helicoverpa armigera is a preferable food for Trichograma chilonis and increased with passage of time along with each release up to one month. These results are in conformity with those of Usman et al. (2012) who used Trichogramma chilonis in field, reported positive results in controlling lepidopterous pests of field crops. Sharma et al. (2016) also reported that Trichogramma chilonis are the best bio-control agents for controlling tomato fruit borer after conducting field experiments in tomato crop.

Table 3. Mean percent infestation of tomato fruit borer treated with different releases of Tricho/cards during 2017

\begin{tabular}{lllll}
\hline S. No. & Treatments & Dose & Percent infestation & Protection over control \\
\hline 1 & T1 & 16000 eggs t.c. & $5.860 \mathrm{c}$ & $80.40 \mathrm{a}$ \\
2 & $\mathrm{~T} 2$ & 14000 eggs t.c. & $7.547 \mathrm{bc}$ & $71.19 \mathrm{~b}$ \\
3 & $\mathrm{~T} 3$ & 12000 eggs t.c. & $9.397 \mathrm{~b}$ & $67.31 \mathrm{c}$ \\
4 & $\mathrm{~T} 4$ & untreated & 19.770 & \\
\hdashline $\mathrm{LSD}_{0.05}$ & & & \\
\hline
\end{tabular}

Note. Means in each column followed by different letter(s) are significantly different at $5 \%$ level of significance $(\mathrm{p}>0.05)$ by LSD.

\subsection{Effect of Different Releases of Trichogramma chilonis on the Yield of Tomato Crop}

Significant difference in percent infestation of tomato fruit borer as affected by various releases of Trichograma chilonis population was recorded (Table 4). The lowest percent weight loss (15.96) was recorded in T1 (16000 tricho release) followed by T2 (14000 tricho release) which gave $19.42 \%$ weight loss while the highest (27.31\%) was noted in control plots where no trichograma releases was made. The lowest $\%$ percent weight loss in $\mathrm{T} 1$ treatment might be due to highest population of trichograma which parasitized the maximum number of borer egg and larvae as well. Our results are in similarity with the result obtained by Usman et al. (2012) who reported that maximum number of tricho-eggs installed in field gives minimum infestation of fruit borer. Data regarding tomato fruit yield also depicted significant different among treatments. The maximum fruit yield $\left(5533.1 \mathrm{~kg} \mathrm{ha}^{-1}\right)$ was recorded in T1 (16000 tricho release) followed by T2 (14000 tricho release) and T3 (12000 tricho release) which gave 4820.6 and $4735.8 \mathrm{~kg} \mathrm{ha}^{-1}$ fruit yield respectively. The lowest fruit yield of $\left(2820.5 \mathrm{~kg} \mathrm{ha}^{-1}\right)$ was found in control treatment (T4) where no trichograma cards were installed (Table 4). The significant increase in tomato fruit yield as compared to control (T4) might be due to the release effectiveness of Trichograma chilonis in parasitizing the eggs and larvae's of tomato fruit borer, when released in higher population parasitized the host very efficiently. The control treatment indicated the highest infestation of fruit borer and resulted in maximum fruit drop. In this case our results coincide with (Muhammad et al., 2008) who achieved similar results while working on effectiveness of Trichogramma chilonis against tomato fruit borer and revealed it as an eco-friendly approach.

Table 4. Effect of different releases of Trichogramma chilonis on the yield of tomato crop

\begin{tabular}{lllll}
\hline Treatments & Percent weight loss & \% Weight loss reduction over control & Yield $\mathbf{( k g / h )}$ & \% Yield increase over control \\
\hline $\mathrm{T} 1$ & $15.96 \mathrm{~d}$ & 40.59 & $5533.1 \mathrm{a}$ & $96.26 \mathrm{a}$ \\
$\mathrm{T} 2$ & $19.42 \mathrm{c}$ & 28.90 & $4820.6 \mathrm{~b}$ & $74.36 \mathrm{~b}$ \\
$\mathrm{~T} 3$ & $21.29 \mathrm{~b}$ & 22.05 & $4735.8 \mathrm{c}$ & $67.70 \mathrm{c}$ \\
$\mathrm{T} 4$ & $27.31 \mathrm{a}$ & & $2820.5 \mathrm{~d}$ & \\
\hline $\mathrm{LSD}_{0.05}$ & 0.6383 & & 100.78 & 0.3989 \\
\hline
\end{tabular}

Note. Means in each column followed by different letter(s) are significantly different at $5 \%$ level of significance $(\mathrm{p}>0.05)$ by LSD. 


\subsection{Efficacy of Selected Insecticides Against Tomato Fruit Borer}

The data regarding Borer infestation on weekly interval and its control by various insecticides is presented in graph-2. The graph indicates that there is a big variation in borer attack regarding crop growth from week 1 to week 12. The general trend of borer infestation showed that insecticides applied on the crop gave significant control as compared to check, in which the highest level of infestation ( 29 or 30\%) was noted.

The \% infestation in untreated plots (check) showed that with the passage of time, the borer severity also increased. This might be the result of borer multiplication as the new generation came out and attacked the fruit with more severity.

The graph regarding efficacy of applied insecticides during week 1 indicated significant borer control. Comparing the insecticides it is clear that Border showed the best borer control followed by Profit and Capital plus. The least effectiveness was observed in Commando followed by Polytrin-C. The untreated plots showed highest borer infestation. This indicates that Border is the most effective insecticides for the control of fruit borer of tomato due to its active ingredient which either repel or killed the insect. Almost similar borer control trend was observed throughout study period (12 weeks), however \% infestation showed a declining trend up to 12 weeks. It showed the residual effect of insecticide for a long period.

It is concluded that Border proved best in controlling tomato borer among the five insecticides used. Hence it should be recommended for the farming community to apply it as and when required for getting better economic benefits and good quality tomato fruits.

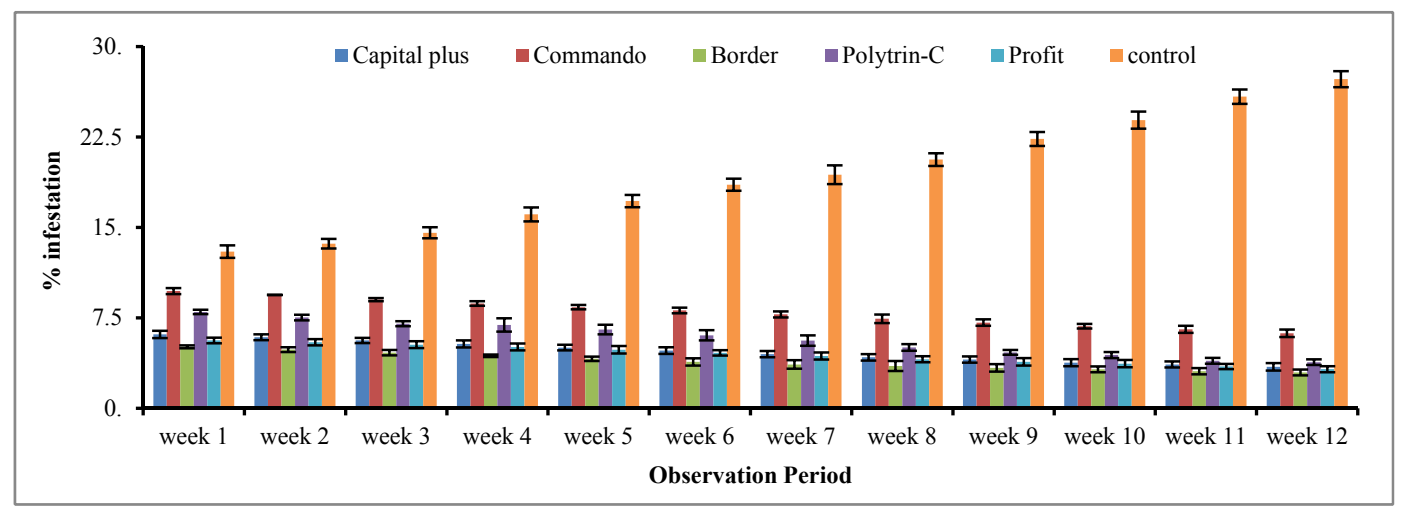

Figure 2. Weekly mean percentages of infestation with Helicoverpa armigera larvae in tomato fields' with five different insecticides at ARI, DI Khan

\subsection{Percent Infestation of Tomato Fruit Worm}

The mean percent fruit infestation after application of insecticides revealed that all the other treatments were efficient and their performance is much better than control plot. Results in Table 5 indicated that percent infestation of tomato fruit worm was significantly different among all the treatments as well as untreated plot. The lowest percent infestation (3.88) of Helicoverpa armigera was recorded when the plot was treated with Border which was followed by Profit (4.46) and Capital Plus (4.70). Percent infestation observed in plots treated with Politrin-C was 5.80. The highest percent infestation was noted in control which was (19.36) followed by Commando showing (7.933) percent infestation.

The application of all insecticides resulted in lower percent infestation which shows significance of insecticides against tomato fruit borer. The reason for the superiority of these chemical insecticides (Border, Rapid, Capital Plus), in reducing percent infestation compared to other insecticides (Commando, Polytrin-C) is probably due to their quicker action against target pest. Results of Ravi et al coincide with our findings (Ravi et al., 2008). They stated that Border $500 \mathrm{ml}$ can be effective by reducing percent infestation of Tomato fruit borer. 
Table 5. Mean percent infestation of tomato fruit worm treated with five different insecticides during 2017

\begin{tabular}{llllll}
\hline S. No. & Treatments & A.I. & Dose/Acre & Mean percent infestation & \% Protection over control \\
\hline 1 & T1 & Capital plus & $500 \mathrm{ml}$ & $4.703 \mathrm{~d}$ & $77.41 \mathrm{c}$ \\
2 & T2 & Commando & $62 \mathrm{~g}$ & $7.933 \mathrm{~b}$ & $64.43 \mathrm{e}$ \\
3 & T3 & Border & $500 \mathrm{ml}$ & $3.887 \mathrm{e}$ & $91.62 \mathrm{a}$ \\
4 & T4 & Polytrin-C & $500 \mathrm{ml}$ & $5.800 \mathrm{c}$ & $67.39 \mathrm{~d}$ \\
5 & T5 & Profit & $200 \mathrm{ml}$ & $4.460 \mathrm{~d}$ & $81.51 \mathrm{~b}$ \\
6 & T6 & Control & $500 \mathrm{ml}$ & $19.367 \mathrm{a}$ & \\
\hline SSD $_{0.05}$ & & & & 0.3872 & \\
\hline
\end{tabular}

Note. Means in each column followed by different letter(s) are significantly different at $5 \%$ level of significance $(p>0.05)$ by LSD.

\subsection{Effect of the Selected Insecticides Treatments on Tomato Yield}

In Table 6 the data showed significant variations among the various treatments (insecticides). The highest percent infestation of $(24.60 \%)$ was observed in control treatment followed by Commondo $(15.40 \%)$ and Polytrin-C (11.55\%). The lowest infestation of (8.64\%) was recorded in Border followed by Profit (9.33\%). The Capital Plus gave intermediate response by having (10.34\%) infestation of fruit borer. The highest efficacy of Border may be due to the active ingredient which caused the maximum damage to the borer, hence reduced its percent infestation.

Data regarding tomato yield as affected by the application of various insecticides for the control of fruit borer showed significant difference among themselves. The maximum fruit yield of $6179.0 \mathrm{~kg} \mathrm{ha}^{-1}$ was recorded when Border was applied followed by Profit which gave the tomato fruit yield of $5914.8 \mathrm{~kg} \mathrm{ha}^{-1}$ while the minimum fruit yield of $2629.5 \mathrm{~kg}^{-1}$ was recorded in control treatment, followed by Commondo which produced fruit yield of $4698.3 \mathrm{~kg}^{-1}$. Next to this "Capital Plus" gave fruit yield of $5794.8 \mathrm{~kg}^{-1}$ fallowed by Polytrin-C $5711.6 \mathrm{~kg} \mathrm{ha}^{-1}$. The results clearly showed that all the insecticide applied to tomato crop gave high tomato yield as compare to check treatment. The variation in fruit damage and yield in different sequential application of insecticides might be due to the slow rate of toxicity. In the present study Border application were effective in decreasing the young one population as well as increased the fruit yield and reducing the fruit damage. The results subscribe to the findings of Dharmasena (1993), who also reported superior efficacy of Border against tomato fruit worm on tomato.

Table 6. Effect of different chemical insecticides on the yield of tomato crop

\begin{tabular}{lllll}
\hline Treatments & Percent fruit damage & \% Fruit damage reduction over control & Yield $\mathbf{( k g / h )}$ & \% Yield increase over control \\
\hline Capital plus & $10.34 \mathrm{~d}$ & $55.24 \mathrm{c}$ & $5794.4 \mathrm{c}$ & $118.0 \mathrm{~b}$ \\
Commondo & $15.40 \mathrm{~b}$ & $48.05 \mathrm{e}$ & $4698.3 \mathrm{~d}$ & $78.6 \mathrm{e}$ \\
Border & $8.64 \mathrm{f}$ & $75.20 \mathrm{a}$ & $6179.0 \mathrm{a}$ & $134.9 \mathrm{a}$ \\
Polytrin C & $11.55 \mathrm{c}$ & $62.80 \mathrm{~d}$ & $5711.6 \mathrm{c}$ & $117.21 \mathrm{c}$ \\
Profit & $9.33 \mathrm{e}$ & $69.59 \mathrm{~b}$ & $5914.8 \mathrm{~b}$ & $90.87 \mathrm{~d}$ \\
Control & $24.60 \mathrm{a}$ & & $2629.5 \mathrm{e}$ & \\
\hline LSD $_{0.05}$ & 0.2731 & 101.61 & \\
\hline
\end{tabular}

Note. Means in each column followed by different letter(s) are significantly different at $5 \%$ level of significance $(\mathrm{p}>0.05)$ by LSD.

\subsection{Cost Benefits Analysis of Insecticides and Trichocards}

Economic analysis of the data regarding efficacy of different insecticides vs trichocards for the control of tomato fruit has been presented in Table 7. The highest benefit-cost ratio (BCR) of 46.45 was recorded in trichograma fallowed by Profit which produced the BCR of 25.44, next to this treatment. The insecticide Border also gave comparable BCR of 21.1 which the lowest BCR of 11.71 was noted in commando fallowed by Poltrin-C \& Capital Plus that produced the BCRs of 15.7 and 17.2 respectively. Ullah et al. (2012) also noted the effectiveness of Trichograma chilonis against this pest and got similar results. Trichocards do not need any equipment or skilled person as well as are very economical for application. 
Table 7. Net income per hectare

\begin{tabular}{llllll}
\hline Treatments & Cost of chemical & Cost of spray (Rs) & Total cost & Total income & Net BCR income \\
\hline Capital plus & 2900 & 450 & 3350 & 57934 & 5458417.2 \\
Commondo & 3569 & 450 & 4010 & 46983 & 4297311.71 \\
Border & 2465 & 450 & 2915 & 61790 & 5887521.1 \\
Polytrin C & 3170 & 450 & 3620 & 57116 & 5349615.7 \\
Profit & 1875 & 450 & 2325 & 59148 & 5682325.44 \\
Control & - & - & - & - & - \\
Trichocards & 741 & 450 & 1191 & 55331 & 5414046.45 \\
\hline
\end{tabular}

\subsection{Comparative Percent of Fruit Infestation in Insecticides Application and Trichogramma chilonis Releases}

Comparison of insecticides application \& Trichograma chilonis releases were non-significant to each other, but they were considerably different from the control plot. Pesticides were more effective than trichocard application. However, application of pesticides and the trichocards were significant to each other in case of percent infestation. Therefore, it is suggested that trichocard release can be the best substitute of chemical application. Our results almost coincide with Saljoqi and Walayati (2013) regarding the effectiveness of Trichograma chilonis and insecticide application. Nadeem and Hamed (2011) also reported the usefulness of Trichograma chilonis to reduce the borer attack below economic threshold level (ETL) (Nadeem \& Hamed, 2011).

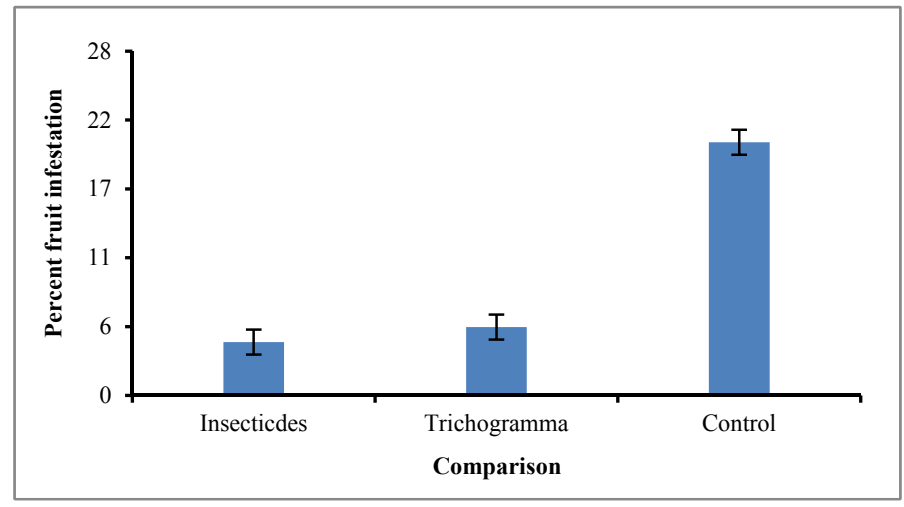

Figure 3. Comparative Percent of fruit infestation in insecticides application and Trichogramma chilonis releases

\section{Conclusion}

Our results revealed that the Trichogramma cards are very effective in managing Helicoverpa armigera in field conditions to control the pest population below economic threshold level (ETL). Helicoverpa armigera is a preferable food for Trichograma chilonis and once suitable stage of the pest is available then results are promising. Effectiveness was increased with passage of time along with each release up to one month. The success is because of their dispersal ability and parasitizing performance.

\section{References}

Heuvelink, E. (2018). Tomatoes. CABI. https://doi.org/10.1079/9781780641935.0000

Hoffmann, M. P., Ode, P. R., Walker, D. L., Gardner, J., van Nouhuys, S., \& Shelton, A. M. (2001). Performance of Trichogramma ostriniae (Hymenoptera: Trichogrammatidae) reared on factitious hosts, including the target host, Ostrinia nubilalis (Lepidoptera: Crambidae). Biological Control, 21, 1-10. https://doi.org/10.1006/bcon.2000.0912

Hussain, D., Hussain, A., Qasim, M., \& Khan, J. (2015). Insecticidal susceptibility and effectiveness of Trichogramma chilonis as parasitoids of tomato fruit borer, Helicoverpa armigera. Pakistan Journal of Zoology, 47. 
Katroju, R. K., Cherukuri, S. R., \& Vemuri, S. B. (2014). Bio-efficacy of insecticides against fruit borer (Helicoverpa armigera) in tomato (Lycopersicon esculentum).

Lange, W. H., \& Bronson, L. (1981). Insect pests of tomatoes. Annual Review of Entomology, 26, $345-371$. https://doi.org/10.1146/annurev.en.26.010181.002021

Li, L.-Y. (1994). Worldwide use of Trichogramma for biological control on different crops: A survey biological control with egg parasitoids.

Muhammad, S., Muhammad, A., Mansoor, U., \& Rana, S. (2008). Integration of some bio pesticides and Trichogramma chilonis for sustainable management of rice leaf folder, Cnaphalocrocis medinalis (Guenee) (Lepidoptera: Pyralidae). Pak J Agric Sci, 45, 69-74.

Nadeem, S., \& Hamed, M. (2011). Biological control of sugarcane borers with inundative releases of Trichogramma chilonis (Ishii) (Hymenoptera: Trichogrammatidae) in farmer fields. Pakistan J Agric Sci, 48, 71-74.

Pimentel, D. (1995). Amounts of pesticides reaching target pests: Environmental impacts and ethics. Journal of Agricultural and Environmental Ethics, 8, 17-29. https://doi.org/10.1007/BF02286399

Ravi, M., Santharam, G., \& Sathiah, N. (2008). Ecofriendly management of tomato fruit borer, Helicoverpa armigera (Hubner). Journal of Biopesticides, 1, 134-137.

Reddy, N. A., \& Kumar, C. A. (2004). Studies on the seasonal incidence of insect pests of tomato in Karnataka. Pest Management in Horticultural Ecosystems, 10, 113-121.

Romeis, J., Babendreier, D., Wäckers, F. L., \& Shanower, T. G. (2005). Habitat and plant specificity of Trichogramma egg parasitoids underlying mechanisms and implications. Basic and Applied Ecology, 6, 215-236. https://doi.org/10.1016/j.baae.2004.10.004

Romeis, J., Bartsch, D., Bigler, F., Candolfi, M. P., Gielkens, M. M., Hartley, S. E., ... Wolt, J. D. (2008). Assessment of risk of insect-resistant transgenic crops to nontarget arthropods. Nature Biotechnology, 26, 203. https://doi.org/10.1038/nbt1381

Saleem, M. Y., Asghar, M., Iqbal, Q., Rahman, A., \& Akram, M. (2013). Diallel analysis of yield and some yield components in tomato (Solanum lycopersicum L.). Pak J Bot, 45, 1247-1250.

Saljoqi, A.-U.-R., \& Walayati, W. K. (2013). Management of Sugarcane Stem Borer Chilo infuscatellus (Snellen) (Lepidoptera: Pyralidae) Through Trichogramma chilonis (Ishii) (Hymenoptera: Trichogrammatidae) and Selective Use of Insecticides. Pakistan Journal of Zoology, 45.

Senthil-Kumar, M., \& Mysore, K. S. (2012). Ornithine-delta-aminotransferase and proline dehydrogenase genes play a role in non - host disease resistance by regulating pyrroline-5-carboxylate metabolism-induced hypersensitive response. Plant, Cell \& Environment, 35, 1329-1343. https://doi.org/10.1111/j.1365-3040. 2012.02492.x

Shah, J., Inayatullah, M., Sohail, K., Shah, S., Iqbal, T., \& Usman, M. (2013). Efficacy of botanical extracts and a chemical pesticide against tomato fruit worm, Helicoverpa armigera (Lepidoptera: Noctuidae). Sarhad $J$ Agric, 29, 93-96.

Sharma, K., Bhardwaj, S., \& Sharma, G. (2011). Systematic studies, life history and infestation by Helicoverpa armigera (Hubner) (Lepidoptera: Noctuidae) on tomato in semi arid region of Rajasthan. Biological Forum-An International Journal, 1, 52-56.

Sharma, S., Devlash, R., Kumar, J., Bala, B., \& Jamwal, R. (2016). Evaluation of IPM modules for the management of fruit borer and fruit rot diseases in tomato, Lycopersicon esculentum Miller. Journal of Applied and Natural Science, 8, 240-244. https://doi.org/10.31018/jans.v8i1.780

Singh, P., Shukla, R., \& Yadav, N. (2012). Bio-efficacy of some insecticides against H. armigera (Hubner) on chickpea (Cicer arietinum L.). Journal of Food Legumes, 25, 291-293.

Stark, J. D., Vargas, R., \& Banks, J. E. (2007). Incorporating ecologically relevant measures of pesticide effect for estimating the compatibility of pesticides and biocontrol agents. Journal of Economic Entomology, 100, 1027-1032. https://doi.org/10.1093/jee/100.4.1027

Talekar, N., Opena, R., \& Hanson, P. (2006). Helicoverpa armigera management: A review of AVRDC's research on host plant resistance in tomato. Crop Protection, 25, 461-467. https://doi.org/10.1016/ j.cropro.2005.07.011 
Ullah, F., Shakur, M., Badshah, H., Ahmad, S., Amin, M., \& Zamin, M. (2012). Efficacy of Trichogramma chilonis Ishii in comparison with two commonly used insecticides against sugarcane stem borer Chilo infuscatellus Snellen (Lepidoptera: Pyralidae). Journal of Animal and Plant Sciences, 22, 463-466.

Usman, A., Khan, I. A., Inayatullah, M., Saljoqi, A. U. R., \& Shah, M. (2013). Appraisal of different tomato genotypes against tomato fruit worm (Helicoverpa armigera Hub.) infestation. Pakistan Journal of Zoology, 45.

\section{Copyrights}

Copyright for this article is retained by the author(s), with first publication rights granted to the journal.

This is an open-access article distributed under the terms and conditions of the Creative Commons Attribution license (http://creativecommons.org/licenses/by/4.0/). 